\title{
Sprout Inhibition in Yam by Gamma Irradiation'
}

\author{
J.R. Rivera, M. A. González, and J. Cuevas-Ruiz ${ }^{2}$ \\ INTRODUCTION
}

"Florido," a yam variety of Dioscorea alata (L.), is a tuber highly regarded by consumers in Puerto Rico. The crop is harvested from October to February and the tubers have a 4-month period of dormancy. Production is thus restricted because of the limited market during the harvest period and the inability to store yam beyond this dormant period. Yam production could be increased if the dormancy period could be prolonged. The dormancy period has been prolonged successfully on an experimental basis by storing fresh tubers under controlled conditions of temperature and relative humidity (5). This method, however, is rather expensive.

The shelf life of certain fruits and vegetables has been increased by the use of gamma irradiation $(1,2,4,6,8,14,15)$. Many of the studies performed include the use of gamma irradiation on tubers, bulbs, and root crops.

Gamma radiation acts with a preservative effect (13) on microorganisms, enzymes and constituents of foods. In tubers, one of these effects is sprout inhibition. At the same time, it has been found that gamma irradiation can also alter product quality, introducing changes in flavor, texture, color, and other quality attributes. It therefore becomes necessary to develop an optimum irradiation dose; one that may extend the life of the product without producing undesirable changes in quality. It has been found that a radiation dose in the range of 10 to $20 \times 10^{8}$ rads is sufficient for most bulb, tuber and root crops (14).

This work was conducted with the purpose of investigating the effect of gamma radiation on the sprouting of $D$. alata yam tubers, to find a dose sufficient to increase the shelf life of the tubers without affecting their quality.

\section{MATERIALS AND METHODS}

Tubers of $D$. alata from the 1971 and 1972 crops were studied. They were bought fresh from a small commercial plantation in the central region of Puerto Rico. The best tubers were selected at the Food Technology Laboratory and placed in ventilated crates of laminated wood, 19 by 12 by 12

1 Manuscript submitted to Editorial Board September 14, 1973.

2 Research Assistant and Director, respectively, Food Technology Laboratory, Agricultural Experiment Station, Mayagüez Campus, University of Puerto Rico, Rio Piedras, P.R.; and Senior Associate, Puerto Rico Nuclear Center, operated by the University of Puerto Rico under contract No. AT (40-1)-1833 for the U.S. Atomic Energy Commission. 
inches, each loaded crate weighing 40 pounds. The crated tubers were stored for 8 days in Forma Scientific environmental rooms with interior dimensions of 5 feet 2 inches wide, 6 feet 6 inches deep and 7 feet 1 inch high. The temperature was set to a range of $29.4^{\circ}$ to $32.2^{\circ} \mathrm{C}$ and the relative humidity at 90 to 95 percent. These conditions were used to cure the tubers and at the same time to heal their cuts. (5)

After the curing treatment in the first year study, the tubers were exposed to 5- or 10-Krad doses of gamma radiation from a cobalt-60 source at the

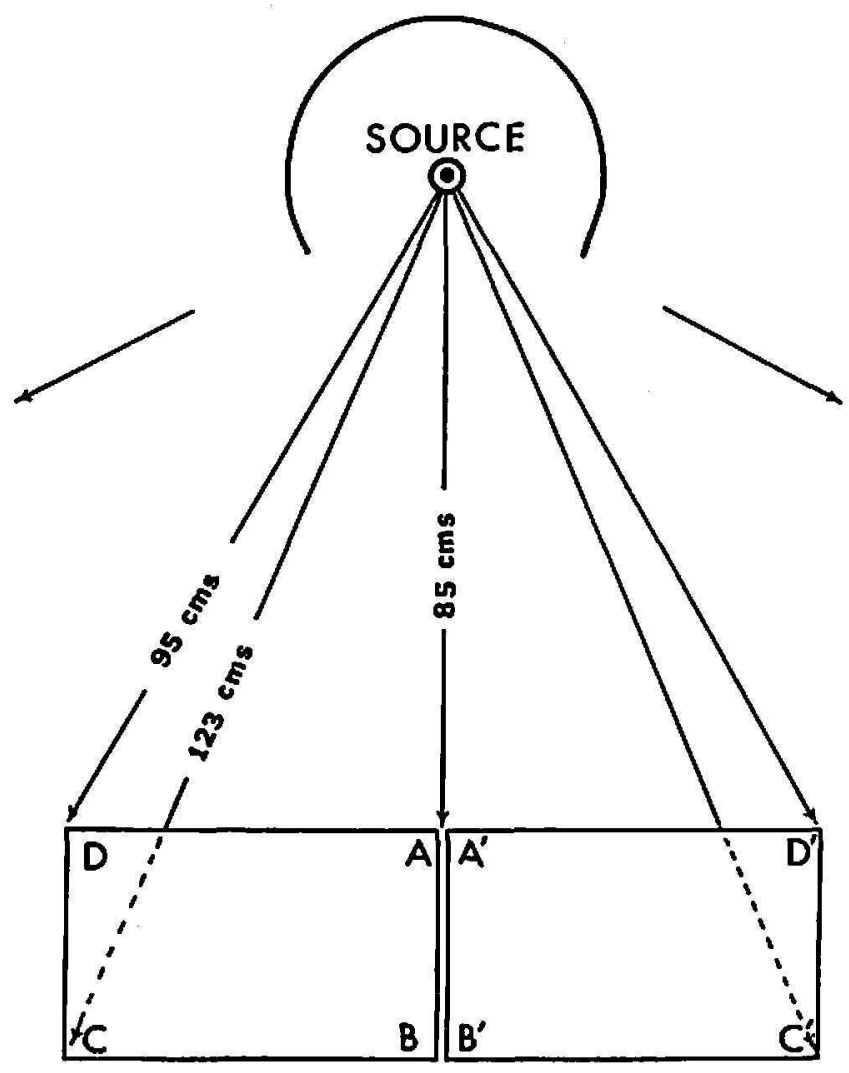

FIG. 1.-Geometry of irradiation set-up.

Puerto Rico Nuclear Center, Río Piedras, at a dose rate of $69 \mathrm{rads} / \mathrm{min}$. The crates were placed at a distance of 1 meter from the source to the center of the crates. Two crates, placed side by side, were irradiated at a time. The exposure time was estimated for each dose and the crates turned around at half the time. In that way, the two opposite sides of the crates were exposed uniformly to the radiation source (fig. 1).

The irradiated and non-irradiated samples (control) of yam were kept in natural storage in a screened, well-ventilated, wooden storage house under prevailing ambient conditions, with temperatures ranging from $21^{\circ}$ to $32^{\circ} \mathrm{C}$ and a relative humidity of 60 to 95 percent. They were inspected and weighed at weekly intervals. Records were kept for sprouting and weight loss. Both irradiated and control samples were cooked and submitted to a 
taste panel for sensory evaluation. Panelists rated the samples on the basis of a five-point hedonic scale where +2 stands for "very acceptable" and -2 for "not acceptable".

The-irradiated and the control samples were also subjected to chemical evaluation. Moisture content was determined by the vacuum-oven method (9). Total and reducing sugars were analyzed following the Moyer and Holgate method (12), using invertase for total sugar determination. The Carter and Neubert method (3) was used for starch determinations, but a $7.8 \mathrm{~N}$ concentration was employed for the digestion of samples instead of $6 \mathrm{~N}$ $\mathrm{HClO}_{4}$. The density of the samples was determined by measuring the volume of water displaced by a known weight of the peeled tuber and the results expressed as $\mathrm{g} / \mathrm{cc}$. The analysis for ascorbic acid (vitamin $\mathrm{C}$ ) was made by the 2,4-dinitrophenylhydrazine method (10). Texture determinations were performed using a Food Technology Corporation electrical recording and indicating texture instrument with a 3,000-pound proving ring and the range set at 1,500 pounds. The plunger was adjusted to a 1-minute stroke, a time force curve was recorded, the maximum force applied was read directly from the chart, and the area under the curve was determined using a planimeter. A standard shear cell packed full was used for each determination. The sample was placed in the cell with the fibers perpendicular to the path of the knives.

In the second year study an intermediate dose of $7.5 \mathrm{Krad}$ was also tried to determine the optimum dose as it was noted that the 10-Krad dose was too high.

\section{RESULTS AND DISCUSSION}

The effect of radiation on sprouting of yam tubers after storage at ambient conditions for 200 days is shown in figure 2. Tubers exposed to 10-, 7.5-, and 5-Krad doses sprouted in the order of 3, 9, and 45 percent, respectively, while 100 percent of the control samples sprouted. Compared with the control, tubers exposed to doses of 7.5 and $10 \mathrm{Krad}$ sprouted only slightly. No additional sprouting occurred after 160 days of storage. Sprouts of control tubers continued growing after 160 days. The small sprouts of irradiated tubers progressively dried out but the tubers were as good in quality as non-sprouted ones at all times.

Figure 3 shows weight losses for irradiated and non-irradiated tubers stored at ambient conditions. Irradiated tubers exposed to the three different doses maintained a similar pattern of weight loss and at the end of the 200 days in storage their weight losses ranged between 21.10 and 21.70 percent, while in the control tubers it was 39.85 percent. By comparing figures 2 and 3 , it can be noted that at 120 days in storage (when a sharp increase in sprouting was observed), considerable weight loss had also 


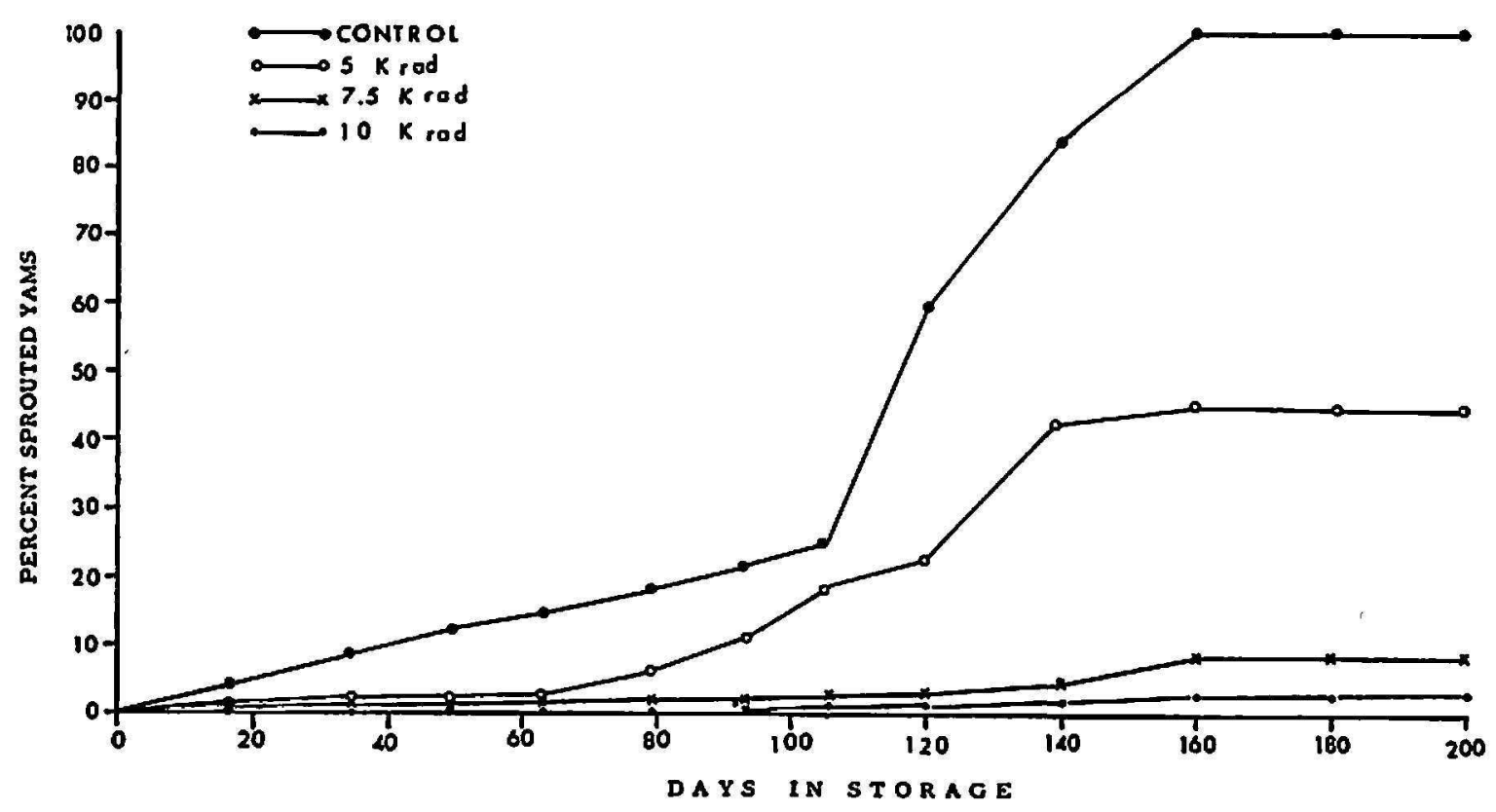

FIG. 2.-Use of irradiation $(5,7.5$ and $10 \mathrm{Krad})$ as sprout inhibitor in $D$. alata yam tubers stored at ambient conditions.

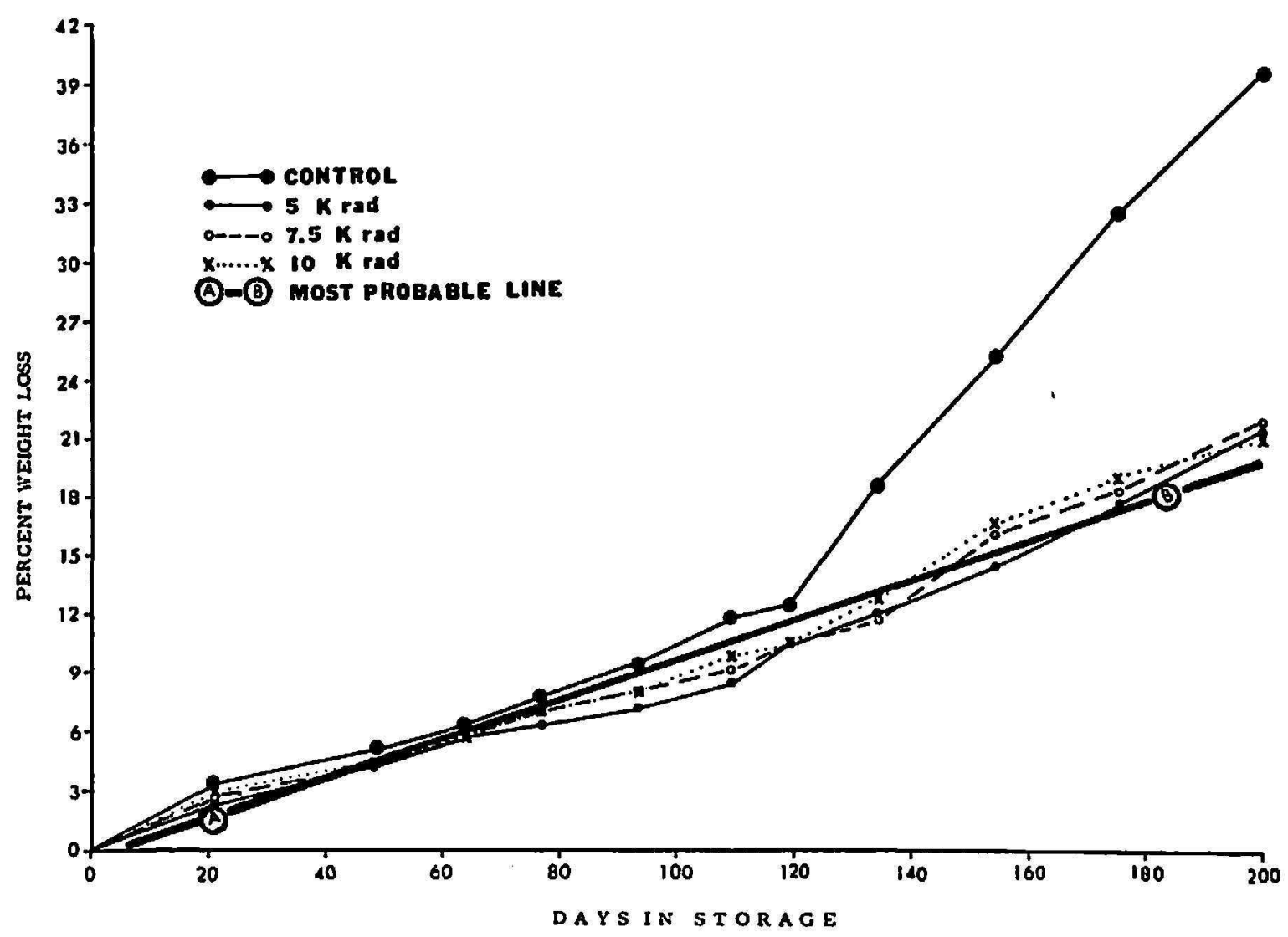

FIG. 3.-Percent weight loss of irradiated $D$. alata yam tubers after 7 months in storage (November 1972 to June 1973) at ambient conditions. 
taken place, probably because of the higher metabolic rate and the larger surface which the sprouts exposed for transpiration. In figure 3 , line AB (assuming a straight line influence of time on weight loss) is the most probable line calculated for the data obtained from the weight loss in the irradiated tubers. It shows that weight loss found over this line resulted from sprouting, while the weight loss under this line is the result of the normal loss in weight induced by storage.

Table 1 shows the changes in sensory evaluation during their storage period for the irradiated and non-irradiated tubers stored at ambient conditions. Comparing the average results obtained after 200 days in storage it was found that the tubers irradiated with $10-\mathrm{Krad}$ doses had a sweet taste, which is not characteristic of yam, for which reason its average rating was

TABLE 1.-Resulls of sensory evaluation' performed on D. alata yam tubers stored at ambient conditions

\begin{tabular}{ccccc}
\hline Treatments & $\begin{array}{c}\text { Before } \\
\text { irradiation }\end{array}$ & $\begin{array}{c}\text { Immediately } \\
\text { after irradiation }\end{array}$ & $\begin{array}{c}70 \text { days after } \\
\text { irradiation }\end{array}$ & $\begin{array}{c}200 \text { days after } \\
\text { irradiation }\end{array}$ \\
\hline Non-treated (control) & 1.0 & 1.00 & 0.70 & 0.50 \\
$5.0 \mathrm{Krad}$ & 1.0 & 0.80 & 0.80 & 0.85 \\
7.5 Krad & 1.0 & 0.78 & 0.70 & 0.70 \\
$10.0 \mathrm{Krad}$ & 1.0 & 0.90 & 0.90 & 0.65 \\
\hline
\end{tabular}

1 Five-point hedonic scale where +2 stands for "very acceptable" and -2 for "not acceptable".

low compared with the tubers irradiated at 5- and 7.5-Krad doses. The control sample was rated very low because, while not sweet, it had dried out and had acquired a gummy texture. In general, no change in flavor took place during storage when the tubers were irradiated at 5- and 7.5-Krad doses.

Table 2 shows the results of analyses performed on the tubers before, immediately after, and 70 and 200 days after irradiation.

There was no appreciable difference in moisture content between the irradiated and the control samples; nevertheless, after 200 days in storage the moisture content of all the samples decreased, the lowest being in the control.

No variation was noted in the starch content between irradiated and non-irradiated samples for the first 70 days; however, after 200 days in storage the starch content in the irradiated yam decreased slightly as the irradiation dosage increased. By contrast, the starch content of the control samples increased.

No significant changes took place in the total sugar content of the control 
TABLE 2.-Results of analyses performed on D. alats tubers stored at ambient conditions

\begin{tabular}{|c|c|c|c|c|c|c|c|}
\hline Treatments & $\begin{array}{c}\text { Date of } \\
\text { analyses }\end{array}$ & $\begin{array}{c}\text { Mois- } \\
\text { ture }\end{array}$ & Starch & Texture & $\begin{array}{l}\text { Total } \\
\text { sugar }\end{array}$ & Vitamin C & Density \\
\hline & & Perc & ent* & Sq. in/g"* & $\frac{198 /}{25} \mathrm{ml}$ & $\mathbf{M g} / 100 \mathrm{~g}$ & $G / C G$ \\
\hline $\begin{array}{l}\text { Non-treated } \\
\text { (control) } \\
5 \mathrm{Krad} \\
7.5 \mathrm{Krad} \\
10 \mathrm{Krad}\end{array}$ & $\begin{array}{l}\text { Before } \\
\text { irradiation }\end{array}$ & $\begin{array}{l}68 \\
68 \\
68 \\
68\end{array}$ & $\begin{array}{l}26 \\
26 \\
26 \\
26\end{array}$ & $\begin{array}{l}9.50 \\
9.50 \\
9.50 \\
9.50\end{array}$ & $\begin{array}{l}0.90 \\
.90 \\
.90 \\
.90\end{array}$ & $\begin{array}{l}11.00 \\
11.00 \\
11.00 \\
11.00\end{array}$ & $\begin{array}{l}1.0 \\
1.08 \\
1.08 \\
1.08 \\
1.08\end{array}$ \\
\hline $\begin{array}{l}\text { Non-treated } \\
\text { (control) } \\
5 \mathrm{Krad} \\
7.5 \mathrm{Krad} \\
10 \mathrm{Krad}:\end{array}$ & $\begin{array}{l}\text { Immediately } \\
\text { after } \\
\text { irradiation }\end{array}$ & $\begin{array}{l}68 \\
68 \\
68 \\
68\end{array}$ & $\begin{array}{l}26 \\
26 \\
26 \\
26\end{array}$ & $\begin{array}{l}9.50 \\
9.56 \\
9.63 \\
9.80\end{array}$ & $\begin{array}{l}.90 \\
.93 \\
.95 \\
.98\end{array}$ & $\begin{array}{l}11.00 \\
10.08 \\
10.00 \\
10.00\end{array}$ & $\begin{array}{l}1.08 \\
1.08 \\
1.09 \\
1.10\end{array}$ \\
\hline $\begin{array}{l}\text { Non-treated } \\
\text { (control) } \\
5 \mathrm{Krad} \\
7.5 \mathrm{Krad} \\
10 \mathrm{Krad}\end{array}$ & $\begin{array}{c}70 \text { days after } \\
\text { irradiation }\end{array}$ & $\begin{array}{l}64 \\
64 \\
64 \\
64\end{array}$ & $\begin{array}{l}27 \\
27 \\
27 \\
27\end{array}$ & $\begin{array}{l}11.02 \\
13.50 \\
14.05 \\
14.27\end{array}$ & $\begin{array}{r}.91 \\
.92 \\
.99 \\
1.00\end{array}$ & $\begin{array}{r}10.13 \\
10.00 \\
10.00 \\
\therefore \quad 9.50\end{array}$ & $\begin{array}{l}1.11 \\
1.09 \\
1.11 \\
1.12\end{array}$ \\
\hline $\begin{array}{l}\text { Non-treated } \\
\text { (control) } \\
5 \mathrm{Krad} \\
7.5 \mathrm{Krad} \\
10 \mathrm{Krad}\end{array}$ & $\begin{array}{l}200 \text { days after } \\
\text { irradiation }\end{array}$ & $\begin{array}{l}60 \\
64 \\
64 \\
63\end{array}$ & $\begin{array}{l}28 \\
27 \\
23 \\
21\end{array}$ & $\begin{array}{l}22.33 \\
13.80 \\
13.95 \\
14.41\end{array}$ & $\begin{array}{r}.90 \\
.92 \\
1.02 \\
1.60\end{array}$ & $\begin{array}{l}9.53 \\
9.00 \\
8.50 \\
8.20\end{array}$ & $\begin{array}{l}1.26 \\
1.14 \\
1.21 \\
1.27\end{array}$ \\
\hline
\end{tabular}

* Expressed on dry-weight basis.

** Values obtained by multiplying the ratio (area under the curve/weight of sample) by $10^{-8}$.

samples during storage. The irradiated samples underwent some change, however, with an increase in dose and time of storage. Comparing the resulting starch content and total sugar content of the sample irradiated with 10-Krad doses after 200 days in storage, it can be noted that the starch decreased and the total sugar increased with respect to the control. This change could possibly have been the result of starch hydrolysis which pro-. duces sugar (11).

It may be noted that the content of ascorbic acid showed a decrease with storage time after $\mathbf{7 0}$ days, and more so at 200 days.

It was found that the samples increased in hardness and density with increasing storage time; and that after 200 days it was more so in the control increase in hardness than in the irradiated ones, possibly because of the softening effect of gamma irradiation. 


\section{SUMMARY}

The effects of gamma irradiation on sprouting and on the chemical changes which take place in "Florido" variety of Dioscorea alata yam tubers grown in Puerto Rico, were investigated. Irradiation with 7.5-Krad doses did not have appreciable effects on the chemical composition of the tubers but prolonged their dormancy period by 4 additional months. It is suggested that 7.5 Krad is the optimum dose for the inhibition of sprouting in this variety of yam. This treatment makes possible the availability of good quality yam tubers out of season. The loss in weight of the treated tubers was relatively low. Irradiated tubers were found very acceptable by sensory evaluation.

\section{RESUMEN}

Se estudiaron los efectos de la radiación gamma en la germinación de la variedad del ñame ( $D$. alata) Florido cultivado en Puerto Rico y en los cambios químicos que tienen lugar en el tubérculo. La radiación con dosis de $7.5 \mathrm{Krad}$ no afectó apreciablemente su composición y prolongó por 4 meses más el período de inactividad del ñame. Se sugiere una dosis de 7.5 Krad como la óptima para inhibir la germinación de los tubérculos del ñame de esta variedad. Esto hace posible que haya disponible name de buena calidad fuera de temporada. Las pérdidas en peso fueron relativamente bajas y el sabor del tubérculo muy aceptable.

\section{LITERATURE CITED}

1. Beraha, L., Smith, M. A., and Wright, W. R., Gamma radiation dose response of some decay pathogens, Phytopathology 50: 474-6, 1960.

2. Brownell, L. W., et al., Storage properties of gamma irradiated potatoes, Food Technol. 11: 306-12, 1957.

3. Carter, G. H., and Neubert, A. M., Rapid determination of starch in apples, J. Agr. Food Chem. 2 (21): 1,070-2, 1954.

4. Cuevas-Ruiz, J., Graham, H. D., and Luse, R. A., Gamma Radiation Effects on Biochemical Components of Puerto Rican Mangoes, J. Agr. Univ. P. R., 56 (1): 26-32, 1972.

5. Gonzßlez, M. A., and Collazo de Rivera, A., Storage of fresh yam, Dioscorea alata, under controlled conditions, J. Agr. Univ. P.R., 56 (1): 46-56, 1972.

6. Jiravatana, V., Cuevas-Ruiz, J., and Graham, D. H., Extension of Storage Life of Papayas Grown in Puerto Rico by Gamma Radiation Treatments, J. Agr. Univ. P.R., 54 (2): 314-19, 1970.

7. Macqueen, K. F., Sprout inhibitor of vegetables using gamma radiation. Radiation preservation of foods, NAS/NRC. 1273, pp. 127-40, 1965.

8. Massey, L. M., Jr., and Bourke, J. B., Some radiation-induced changes in fresh fruit and vegetables. Radiation Preservation of Foods, Advances in Chemistry Series 65 ACS, Amer. Chem. Soc., Washington, D.C., pp. 1-11, 1967.

9. Methods of Analysis of the Association of Official Agricultural Chemist, 9th ed., Washington, D.C., p. 272, 1960.

10. Methods of Vitamin Assay, 2d ed., Interscience Publishers, Inc., New York, N.Y., 1951. 
11. Morrison, R. T., and Boyd, R. N., Organic chemistry, Allyn and Bacon, Inc., Boston, Mass., p. 1,027, 1966.

12. Moyer, J. C., and Holgate, K. C., Determination of alcohol insoluble solids and sugar content of vegetables, Anal. Chem. 20 (5) : 472-4, 1948.

13. Potter, N. N., Food Science, The Avi Publishing Company, Inc., Westport, Conn., p. 126 and ch. 11, 1968.

14. Salunkhe, D. K., Gamma radiation effects on fruits and vegetables, Econ. Bot. 15: 28-56, 1961.

15. Talburt, W., and Smith, F., ORA, Potato Processing, The Avi Pub. Co., Inc., Westport, Conn., pp. 160-1, 1967. 